\title{
SPECIES DIFFER IN RESPONSES TO TREE SHELTERS
}

\section{by Henry D. Gerhold}

\begin{abstract}
Effects of tree shelters on height, caliper, and diameter at breast height of 11 landscape tree species and cultivars were investigated in 2 nurseries during a 4-year period; the ratio of height to caliper was calculated as an indicator of trunk sturdiness. Species differed greatly in their responses, ranging in the fourth year from none to $44 \%$ and 55\% height increases of Magnolia 'Merrill' and $M$. stellata accompanied by $18 \%$ and $14 \%$ caliper increases. Acer griseum, Carpinus caroliniana, Cercis canadensis, Cornus 'Celestial' and 'Constellation', Prunus serrulata 'Kwanzan', and $P$. subhirtella autumnalis exhibited more modest height increases, but also caliper decreases, compared to controls without shelters. Malus 'Adirondack' and Syringa reticulata 'Summer Snow' did not benefit. Two shelter sizes and severe winter weather also affected the results of some varieties.

Key Words. Landscape trees; nursery; tree shelters; accelerated growth.
\end{abstract}

Tree shelters may be able to accelerate the growth of certain species that are compatible with overhead utility lines. If their slow growth and branching habit could be improved, the limited number of species suitable for planting under wires could be amplified. A previous article (Witmer et al. 1997) discussed the growth responses of 14 species and cultivars grown in tree shelters for 1 or 2 years in 2 nurseries. Two years later, the trees nearly had attained marketable sizes, so that final results of the experiments can be reported now.

Other studies of tree shelters in nursery environments have been conducted in California (Burger et al. 1992; Burger et al. 1996; Burger et al. 1997). The most common use of tree shelters has been in forest conditions (Brissette 1995), but they also have been employed in urban situations (Jones et al. 1995).

\section{MATERIALS AND METHODS}

The earlier report on the 2 experiments (Witmer et al. 1997) described materials and methods completely, so only the main features are repeated here.

Trees in Experiment 1 were planted in May 1994 at Root's Nursery in southeastern Pennsylvania, lo- cated in USDA Hardiness Zone 6. Seven species and cultivars were planted in 6-tree plots, replicated in 3 randomized complete blocks. Tubex ${ }^{\circledR}$ tree shelters 8 to $11 \mathrm{~cm}$ (3.1 to $4.5 \mathrm{in}$.) in diameter and $1.5 \mathrm{~m}(5 \mathrm{ft})$ in height were placed over 3 trees in a subplot; the other 3 trees served as controls. After the second growing season, shelters were removed from 2 trees in each subplot and from the remaining tree after the third season.

Trees in Experiment 2 were planted in April and May 1995 at Nittany Trees nursery in central Pennsylvania, near the border of USDA Hardiness Zones 5 and 6 . Nine species or cultivars were planted in 9tree plots, replicated in 3 randomized complete blocks. Two sizes of Tree Pro Sr. ${ }^{\circledR}$ Tree Protectors were used, $9 \mathrm{~cm}$ (3.5 in.) and $18 \mathrm{~cm}$ (7 in.) in diameter, both $1.5 \mathrm{~m}(5 \mathrm{ft})$ in height; each size was placed over 3 trees in a subplot, leaving 3 trees as controls. Shelters were removed after the second or third growing season, as they had been at Root's Nursery.

Trees were measured every year after summer growth was complete: total height, caliper at $15 \mathrm{~cm}$ (6 in.) above ground, and diameter at $137 \mathrm{~cm}$ (4.5 ft). An indicator of trunk sturdiness was calculated by dividing caliper by height.

Analyses of variance were conducted in which blocks, tree varieties, and shelter treatments within varieties were the main sources of variation. Duncan's New Multiple Range Test was used to separate means at the 0.05 significance level.

\section{RESULTS}

Statistically significant differences were detected among varieties and among tree shelter treatments nested within varieties (Table 1). These occurred in all years in measurements of height, caliper, and diameter at breast height. Blocks and interactions of blocks with varieties and treatments had much smaller effects, which were nonsignificant in most cases.

Three species suffered severe dieback and mortality presumably due to low winter temperatures: Acer 
Table 1. Results of analyses of variance in height, caliper, and diameter at breast height at Root's Nursery and Nittany Trees Nursery.

\begin{tabular}{llllll}
\hline & \multicolumn{5}{c}{ Source of Variation } \\
\cline { 2 - 6 } Variable & Varieties & Shelters(v) & Blocks & $\mathrm{b} \times \mathrm{v}$ & $\mathrm{b} \times \mathrm{s}(\mathrm{v})$ \\
\hline Root's Nursery & & & & & \\
height year 1 & $*$ & $*$ & $\mathrm{~ns}$ & $\mathrm{~ns}$ & $\mathrm{~ns}$ \\
height year 2 & $*$ & $*$ & $\mathrm{~ns}$ & $*$ & $\mathrm{~ns}$ \\
height year 3 & $*$ & $*$ & $\mathrm{~ns}$ & $\mathrm{~ns}$ & $\mathrm{~ns}$ \\
height year 4 & $*$ & $*$ & $*$ & $\mathrm{~ns}$ & $\mathrm{~ns}$ \\
caliper year 2 & $*$ & $*$ & $\mathrm{~ns}$ & $*$ & $*$ \\
caliper year 3 & $*$ & $*$ & $\mathrm{~ns}$ & $*$ & $\mathrm{~ns}$ \\
caliper year 4 & $*$ & $*$ & $*$ & $\mathrm{~ns}$ & $\mathrm{~ns}$ \\
dbh year 2 & $*$ & $*$ & $\mathrm{~ns}$ & $\mathrm{~ns}$ & $\mathrm{~ns}$ \\
dbh year 3 & $*$ & $*$ & $\mathrm{~ns}$ & $\mathrm{~ns}$ & $\mathrm{~ns}$ \\
dbh year 4 & $*$ & $*$ & $\mathrm{~ns}$ & $\mathrm{~ns}$ & $\mathrm{~ns}$ \\
Nittany Trees & & & & & \\
height year 1 & $*$ & $*$ & $\mathrm{~ns}$ & $\mathrm{~ns}$ & $\mathrm{~ns}$ \\
height year 2 & $*$ & $*$ & $\mathrm{~ns}$ & $\mathrm{~ns}$ & $\mathrm{~ns}$ \\
height year 3 & $*$ & $*$ & $*$ & $\mathrm{~ns}$ & $\mathrm{~ns}$ \\
caliper year 1 & $*$ & $*$ & $\mathrm{~ns}$ & $\mathrm{~ns}$ & $*$ \\
caliper year 2 & $*$ & $*$ & $*$ & $*$ & $\mathrm{~ns}$ \\
caliper year 3 & $*$ & $*$ & $*$ & $*$ & $\mathrm{~ns}$ \\
dbh year 1 & $*$ & $*$ & $*$ & $\mathrm{~ns}$ & $\mathrm{~ns}$ \\
dbh year 2 & $*$ & $*$ & $\mathrm{~ns}$ & $*$ & $\mathrm{~ns}$ \\
dbh year 3 & $*$ & $*$ & $\mathrm{~ns}$ & $\mathrm{~ns}$ & $\mathrm{~ns}$ \\
\hline - & $*$ & & &
\end{tabular}

* = significant at $0.05 \%$ level.

$\mathrm{ns}=$ nonsignificant.

capillipes (24 of 30 trees died), Acer davidii (all 30 trees died), and Carpinus japonica ( 7 trees in shelters died and 9 trees in shelters had dieback, whereas 9 control trees were healthy). Therefore, these species were excluded from the analyses.

Trees that remained in shelters for 3 growing seasons had similar dimensions as those sheltered only 2 years. Accordingly, these 2 groups were treated as one in the analyses.

Heights of most varieties within 9-cm (3.5-in.) shelters increased greatly by the end of the second year but only moderately in the case of Malus 'Adirondack' (Table 2). The heights were even greater in the 18-cm (7-in.) shelters, except for the 2 Prunus varieties. At the end of the second growing season, most trees had emerged

* Some trees exhibited dieback.

Metric equivalents: $1 \mathrm{ft}=30.5 \mathrm{~cm}$. from the tops of the shelters. In subsequent years, the height advantages became smaller. Beneficial effects on heights of the 2 magnolias at Root's Nursery and Carpinus caroliniana in the larger shelters at Nittany Trees were especially dramatic, and the height advantage persisted after removal of the shelters. Acer griseum and Cercis canadensis also retained a height advantage after the fourth growing season.

Harsh winters presumably caused some dieback in 1996 or 1997 at Nittany Trees. Practically all of the affected trees were within shelters: 4 of 9 Carpinus trees in each of the shelter sizes, 8 of 9 Magnolia trees in each of the shelter sizes, 3 of 9 Cornus 'Celestial' trees in small shelters, and 2 of 9 Cornus 'Constellation' trees in small shelters.

The caliper growth of trees in shelters was greatly depressed by the end of the second growing season in most cases (Table 3 ). The 2 magnolias were an exception at both nurseries, even though their height growth as a percentage

Table 2. Heights of trees (feet) grown for the first 2 years at Root's Nursery in 9-cm (3.5-in.) shelters and at Nittany Trees in 9- and 18-cm (3.5- and 7-in.) shelters, compared to trees grown all 4 years without shelters (percentage of control).

\begin{tabular}{|c|c|c|c|c|c|c|c|c|c|}
\hline \multirow[b]{2}{*}{ Species, cultivar } & \multicolumn{5}{|c|}{ Feet } & \multicolumn{4}{|c|}{ Percent } \\
\hline & 0 & 1 & 2 & 3 & 4 & 1 & 2 & 3 & $\overline{4}$ \\
\hline \multicolumn{10}{|l|}{ Root's Nursery, $9 \mathrm{~cm}$} \\
\hline Acer griseum & 3.2 & 3.8 & 5.2 & 5.1 & 5.7 & 99 & 131 & 116 & 108 \\
\hline Cercis canadensis & 3.8 & 5.9 & 7.8 & 8.3 & 8.8 & 161 & 129 & 123 & 112 \\
\hline Cornus 'Celestial' & 3.7 & 5.9 & 8.1 & 8.0 & 8.9 & 137 & 124 & 102 & 96 \\
\hline Malus 'Adirondack' & 4.0 & 4.7 & 6.1 & 6.7 & 6.7 & 108 & 108 & 95 & 84 \\
\hline Magnolia 'Merrill' & 3.6 & 4.9 & 7.1 & 7.8 & 8.1 & 136 & 162 & 162 & 144 \\
\hline Magnolia stellata & 1.0 & 2.9 & 5.7 & 6.2 & 7.0 & 219 & 265 & 195 & 155 \\
\hline Syringa 'Summer Snow' & 3.0 & 3.4 & 4.5 & 5.8 & 6.4 & 113 & 119 & 103 & 82 \\
\hline \multicolumn{10}{|l|}{ Nittany Trees, $9 \mathrm{~cm}$} \\
\hline Carpinus caroliniana & 2.6 & 2.7 & 6.3 & $4.9^{*}$ & & 101 & 160 & 100 & \\
\hline Cornus 'Celestial' & 3.2 & 3.2 & 5.5 & $5.2^{*}$ & & 103 & 117 & 114 & \\
\hline Cornus 'Constellation' & 3.8 & 3.6 & 6.2 & $6.6^{*}$ & & 101 & 108 & 102 & \\
\hline Magnolia stellata & 1.9 & 1.8 & 4.5 & $2.8^{*}$ & & 104 & 161 & 88 & \\
\hline Prunus serrulata 'Kwanzan' & 3.1 & 3.1 & 9.1 & 9.0 & & 101 & 130 & 107 & \\
\hline Prunus subhirtella autumnalis & 3.7 & 3.6 & 8.9 & 8.6 & & 95 & 119 & 108 & \\
\hline \multicolumn{10}{|l|}{ Nittany Trees, $18 \mathrm{~cm}$} \\
\hline Carpinus caroliniana & 2.6 & 2.8 & 7.4 & $7.3^{*}$ & & 105 & 189 & 149 & \\
\hline Cornus 'Celestial' & 3.2 & 3.2 & 6.4 & 6.8 & & 102 & 137 & 130 & \\
\hline Cornus 'Constellation' & 3.8 & 4.0 & 7.2 & 7.7 & & 111 & 124 & 119 & \\
\hline Magnolia stellata & 1.9 & 2.1 & 5.6 & $3.2^{*}$ & & 119 & 198 & 102 & \\
\hline Prunus serrulata 'Kwanzan' & 3.1 & 3.1 & 8.9 & 10.3 & & 101 & 126 & 115 & \\
\hline Prunus subhirtella autumnalis & 3.7 & 3.7 & 8.9 & 8.7 & & 99 & 118 & 108 & \\
\hline
\end{tabular}


of the control exceeded all other species. In the fourth year at Root's Nursery, the magnolias were the only varieties for which the calipers of sheltered trees were greater than for the controls. At Nittany Trees, the dieback of sheltered trees, to the ground in many cases, reduced calipers substantially.

The sturdiness indicator of trees within shelters, expressed as caliper of the trunk divided by height, was reduced the most at the end of the second growing season (Table 4). After the tops of trees emerged from shelters and they were removed, sturdiness improved but was still inferior to the controls. The one exception, Malus 'Adirondack', had a higher sturdiness value because its height was depressed by shelters proportionally more than its caliper. The reduction in sturdiness was not a severe problem, but a few trees tended to bend over and were fastened to the stakes that were left in place after shelters were removed. The $18-\mathrm{cm}$ (7-in.) shelters caused less of a reduction in sturdiness than the 9 $\mathrm{cm}$ (3.5-in.) shelters.

Table 3. Calipers of trees (inches) grown the first 2 years at Root's Nursery in 9-cm (3.5-in.) shelters and at Nittany Trees in 9- and 18$\mathrm{cm}$ (3.5- and 7-in.) shelters, compared to trees grown all 4 years without shelters (percentage of control).

\begin{tabular}{|c|c|c|c|c|c|c|c|c|c|}
\hline \multirow[b]{2}{*}{ Species, cultivar } & \multicolumn{5}{|c|}{ Inches } & \multicolumn{4}{|c|}{ Percent } \\
\hline & 0 & 1 & 2 & 3 & 4 & 1 & 2 & 3 & 4 \\
\hline \multicolumn{10}{|l|}{ Root's Nursery, $9 \mathrm{~cm}$} \\
\hline Acer griseum & & & 0.4 & 0.6 & 0.9 & & 60 & 66 & 81 \\
\hline Cercis canadensis & & & 0.7 & 1.4 & 1.9 & & 72 & 91 & 95 \\
\hline Cornus 'Celestial' & & & 0.7 & 1.1 & 1.2 & & 77 & 86 & 86 \\
\hline Malus 'Adirondack' & & & 0.5 & 0.8 & 1.0 & & 66 & 82 & 90 \\
\hline Magnolia 'Merrill' & & & 0.7 & 1.0 & 1.3 & & 97 & 88 & 118 \\
\hline Magnolia stellata & & & 0.5 & 1.0 & 1.4 & & 100 & 106 & 114 \\
\hline Syringa 'Summer Snow' & & & 0.6 & 0.9 & 1.2 & & 61 & 65 & 65 \\
\hline \multicolumn{10}{|l|}{ Nittany Trees, $9 \mathrm{~cm}$} \\
\hline Carpinus caroliniana & 0.2 & 0.1 & 0.4 & $0.5^{*}$ & & 64 & 71 & 56 & \\
\hline Cornus 'Celestial' & 0.4 & 0.4 & 0.5 & $0.6^{*}$ & & 104 & 64 & 69 & \\
\hline Cornus 'Constellation' & 0.4 & 0.4 & 0.6 & $0.7^{*}$ & & 92 & 58 & 63 & \\
\hline Magnolia stellata & 0.2 & 0.2 & 0.4 & $0.3^{*}$ & & 100 & 73 & 54 & \\
\hline Prunus serrulata 'Kwanzan' & 0.4 & 0.4 & 0.9 & 1.3 & & 104 & 67 & 81 & \\
\hline Prunus subhirtella autumnalis & 0.3 & 0.3 & 0.8 & 1.3 & & 96 & 65 & 87 & \\
\hline \multicolumn{10}{|l|}{ Nittany Trees, $18 \mathrm{~cm}$} \\
\hline Carpinus caroliniana & 0.2 & 0.2 & 0.6 & $0.8^{*}$ & & 83 & 98 & 88 & \\
\hline Cornus 'Celestial' & 0.4 & 0.4 & 0.6 & 0.8 & & 112 & 80 & 83 & \\
\hline Cornus 'Constellation' & 0.4 & 0.4 & 0.8 & 0.9 & & 102 & 76 & 80 & \\
\hline Magnolia stellata & 0.2 & 0.2 & 0.5 & $0.5^{*}$ & & 94 & 105 & 85 & \\
\hline Prunus serrulata 'Kwanzan' & 0.4 & 0.4 & 1.0 & 1.5 & & 103 & 79 & 96 & \\
\hline Prunus subhirtella autumnalis & 0.3 & 0.3 & 0.9 & 1.4 & & 104 & 70 & 90 & \\
\hline
\end{tabular}

*Some trees exhibited dieback.

Metric equivalents: $1 \mathrm{ft}=30.5 \mathrm{~cm}$.
The shelters required little maintenance after they were installed shortly after planting. A few of them were bent over by a wet, heavy snowfall because their wooden stakes were defective. Branches inside the shelters remained relatively small. They could be pruned quickly when shelters were taken off. The plastic shelters appeared to deteriorate very little, and could be reused.

\section{DISCUSSION}

Tree shelters were found to be useful in the nursery production of some species but not others. The heights of Magnolia 'Merrill' and Magnolia stellata in shelters were about half again as tall as the controls, and their calipers were also somewhat greater. This size advantage occurred in USDA Hardiness Zone 6 , but near the edge of Zone 5 it was nullified by dieback after severe winters. The modest height increases of Acer griseum, Cercis canadensis, Cornus 'Celestial', and Cornus 'Constellation' in shelters were offset by decreases in caliper and sturdiness; growing them in shelters appears to be advantageous mainly if they are to be sold before they attain $2.5 \mathrm{~cm}$ (1-in.) in caliper. The same may apply to Carpinus caroliniana in 18-cm (7-in.) shelters, but not the 9-cm (3.5-in.) size. Prunus serrulata 'Kwanzan' and Prunus subhirtella autumnalis can attain $2.5 \mathrm{~cm}$ (1 in.) in caliper and 2.7 $\mathrm{m}(9 \mathrm{ft})$ in height in 2 seasons inside $18-\mathrm{cm}$ shelters, but after the third season there may be little advantage. Malus 'Adirondack' and Syringa 'Summer Snow' grew somewhat faster inside shelters for 2 seasons, but the height advantage disappeared afterwards, and caliper growth was inferior at all times.

The 18-cm shelters resulted in superior height and caliper growth compared to the $9-\mathrm{cm}$ shelters and exhibited only minor differences in sturdiness values. In evaluating shelter size, the greater costs for materials and in- 
Table 4. Sturdiness (caliper/height) of trees grown for the first 2 years at Root's Nursery in 9-cm (3.5-in.) shelters and at Nittany Trees in 9- and 18-cm (3.5- and 7-in.) shelters, compared to trees grown all 4 years without shelters (percentage of control).

\begin{tabular}{|c|c|c|c|c|c|c|c|c|}
\hline \multirow[b]{2}{*}{ Species, cultivar } & \multicolumn{4}{|c|}{ Sturdiness } & \multicolumn{4}{|c|}{ Percent } \\
\hline & 1 & 2 & 3 & 4 & 1 & 2 & 3 & 4 \\
\hline \multicolumn{9}{|l|}{ Root's Nursery, $9 \mathrm{~cm}$} \\
\hline Acer griseum & & 0.07 & 0.13 & 0.15 & & 45 & 54 & 75 \\
\hline Cercis canadensis & & 0.09 & 0.17 & 0.21 & & 55 & 74 & 85 \\
\hline Cormus 'Celestial' & & 0.09 & 0.13 & 0.14 & & 62 & 84 & 90 \\
\hline Malus 'Adirondack' & & 0.08 & 0.12 & 0.15 & & 61 & 87 & 107 \\
\hline Magnolia 'Merrill' & & 0.10 & 0.13 & 0.16 & & 60 & 54 & 82 \\
\hline Magnolia stellata & & 0.09 & 0.16 & 0.20 & & 38 & 54 & 74 \\
\hline Syringa 'Summer Snow' & & 0.13 & 0.16 & 0.19 & & 51 & 64 & 79 \\
\hline \multicolumn{9}{|l|}{ Nittany Trees, $9 \mathrm{~cm}$} \\
\hline Carpinus caroliniana & 0.05 & 0.07 & 0.10 & & 69 & 44 & 57 & \\
\hline Cornus 'Celestial' & 0.12 & 0.09 & 0.11 & & 102 & 54 & 64 & \\
\hline Cornus 'Constellation' & 0.11 & 0.09 & 0.11 & & 92 & 54 & 62 & \\
\hline Magnolia stellata & 0.11 & 0.08 & 0.12 & & 96 & 45 & 62 & \\
\hline Prunus serrulata 'Kwanzan' & 0.13 & 0.09 & 0.13 & & 103 & 52 & 75 & \\
\hline Prunus subhirtella autumnalis & 0.07 & 0.09 & 0.15 & & 101 & 54 & 81 & \\
\hline \multicolumn{9}{|l|}{ Nittany Trees, $18 \mathrm{~cm}$} \\
\hline Carpinus caroliniana & 0.06 & 0.08 & 0.11 & & 80 & 52 & 59 & \\
\hline Cornus 'Celestial' & 0.13 & 0.10 & 0.11 & & 110 & 58 & 64 & \\
\hline Cornus 'Constellation' & 0.11 & 0.10 & 0.11 & & 93 & 61 & 67 & \\
\hline Magnolia stellata & 0.09 & 0.09 & 0.16 & & 79 & 53 & 83 & \\
\hline Prunus serrulata 'Kwanzan' & 0.13 & 0.11 & 0.15 & & 102 & 63 & 83 & \\
\hline Prunus subhirtella autumnalis & 0.07 & 0.17 & 0.19 & & 104 & 59 & 84 & \\
\hline
\end{tabular}

Metric equivalents: $1 \mathrm{ft}=30.5 \mathrm{~cm}$.

stallation of the larger ones should be considered in relation to their biological benefits.

Additional benefits of shelters may apply in some situations. Where wildlife problems occur, shelters protect against deer browsing and rubbing their antlers, and also against bark gnawing by mice and voles. Furthermore, pruning can be deferred for 2 years and thus reduce costs and perhaps alleviate the scheduling of labor.

The results of these 2 experiments are consistent with other studies (Burger et al. 1992; Burger et al. 1996; Burger et al. 1997), although the other 2 studies were conducted with different species in a Mediterranean-type climate. Species differed in their responses to shelters. Generally they were taller than controls initially, and caliper growth was reduced. Root growth also was decreased in 1 study (Burger et al. 1997) and can be anticipated in other cases in which calipers are reduced.

\section{CONCLUSIONS}

The utility of tree shelters in the nursery production of smaller types of landscape trees depends on ascertaining biological effects, which then must be evaluated for economic and other practical benefits. The magnitude of height increases and caliper decreases that generally are caused before trees emerge from shelters can differ greatly among species. Tree shelter sizes and variable climatic conditions such as harsh winters also play a role.

Nurseries that may want to use tree shelters to accelerate height growth or protect against wildlife damage should investigate their effectiveness on particular varieties grown under local conditions over a period of at least 4 years. Generally the greatest increases in height and decreases in caliper occur in the first 2 years, after which shelters should be removed. After that time, height advantages decline and caliper growth recovers.

The most encouraging results were obtained with magnolias in a warmer portion of Hardiness Zone 5. Acer griseum, Carpinus caroliniana, Cercis canadensis, and Cornus kousa $\times$ florida hybrids also showed some promise. The faster growing Prunus serrulata and $P$. subhirtella varieties appeared to benefit only marginally. Malus and Syringa reticulata, each represented by only 1 cultivar, grew better without shelters.

\section{LITERATURE CITED}

Brissette, J.C. (Ed.). 1995. Proceedings of the tree shelter conference. USDA Gen. Tech. Report NE-221, 80 pp.

Burger, D.W., G.W. Forister, and R. Gross. 1997. Shortand long-term effects of treeshelters on the root and stem growth of ornamental trees. J. Arboric. 23(2): 49-56.

Burger, D.W., G.W. Forister, and P.A. Kiehl. 1996. Height, caliper growth, and biomass response of ten shade tree species to treeshelters. J. Arboric. 22(4):161-166.

Burger, D.W., P. Švihra, and R. Harris. 1992. Treeshelter use in producing container-grown trees. HortScience 27(1):30-32. 
Jones, R.H., A.H. Chappelka, and D.H. West. 1995. Use of plastic shelters for low-cost establishment of street trees. South. J. Appl. For. 20(2):85-89.

Witmer, R.K., H.D. Gerhold, and E.R. Ulrich. 1997. Tree shelters accelerate slow-growing species in nurseries. J. Arboric. 23(1):40-48.

\section{Professor of Forest Genetics \\ School of Forest Resources \\ Penn State University \\ 109 Ferguson Building \\ University Park, PA 16802}

Résumé. Les effets des ombrières d'arbres sur la hauteur, le calibre (diamètre de la souche) et celui du DHP du tronc ont été étudiés sur 11 espèces et cultivars différents présents dans deux pépinières durant quatre années. Le ratio du calibre par rapport à la hauteur a été calculé comme indice de solidité du tronc. La réponse des espèces variait grandement, de nulle à 45 et $55 \%$ d'accroissement en hauteur pour le Magnolia 'Merrill' et le $M$. stellata accompagnee d'un accroissement du calibre de 18 et 14\%. Acer griseum, Carpinus caroliniana, Cercis canadensis, Cornus 'Celestial', C. 'Constellation', Prunus serrulata 'Kwanzan' et $P$. subhirtella autumnalis avaient des croissances en hauteur plus modeste, mais aussi des diminutions de calibre, comparativement aux arbres-contrôle sans protection. Malus 'Adirondack' et Syringa reticulata 'Summer Snow' sont restés inchangés. Les dimensions des deux ombrières et les conditions climatiques sévères de l'hiver ont aussi affecté les résultats chez certaines variétés.
Zusammenfassung. In einer vierjährigen Periode wurden in zwei Baumschulen die Auswirkungen von Baumschutzhüllen auf die Höhe, Umfang und Durchmesser in Brusthöhe von elf Baumarten untersucht. Das Verhältnis zwischen der Höhe und Umfang wurde dabei als ein Indikator für die Baumvitalität kalkuliert. Die Baumarten reagierten sehr unterschiedlich und rangierten in dem 4 . Jahr von Null bis zu 44 und 55 \% Höhenzuwachs bei der Magnolia 'Merrill' und M. stellata mit 18 und $14 \%$ Umfangzuwachs. Acer griseum, Carpinus caroliniana, Cercis canadensis, Cornus 'Celestial' und 'Constellation', Prunus serrulata 'Kawanzan' und P. subhirtella autumnalis zeigten mehr moderate Höhenzuwachsraten, aber auch schwache Umfangentwichlung im Vergleich mit zwei Kontrollen ohne Schutz. Malus 'Adirondack' und Syringa reticulata 'Summer Snow' profitierten nicht davon. Zwei verschiedene Schutzhüllengrößen und harte Winterbedingungen beeinflußten ebenfalls die Ergebnisse von einigen Baumarten.

Resumen. Los efectos de protectores de árboles en aitura, calibre y diámetro a la altura del pecho de 11 especies de árboles urbanos (de paisaje) y de cultivo fueron investigados en dos viveros durante un periodo de cuatro años. La relación altura a calibre fue calculada como un indicador de la fortaleza del tronco. Las especies tuvieron una gran diferencia en sus respuestas, fluctuando en el cuarto año desde cero hasta 44 y 55 por ciento de incremento en la altura de la Magnolia 'Merril' y M. stellata, acompañado por 18 y 14 por ciento de incremento en el diámetro del tronco. Acer griseum, Carpinus caroliniana, Cercis canadensis, Cornus 'Celestial' y 'Constelación', Prunus serrulata 'Kwanzan' y P. subhirtella autumnalis exhibieron incrementos más modestos en la altura, pero también decreció el diámetro del tronco, comparado con los controles sin protectores. Malus 'Adirondack' y Syringia reticulata 'Summer Snow' no se beneficiaron. Dos tamaños de protector y el clima de un invierno severo también afectaron los resultados de algunas variedades. 